\title{
Long-term changes in blood counts after intraoperative radiotherapy for breast cancer-single center experience and review of the literature
}

\author{
Cornelia Wersal $^{1}$, Anke Keller ${ }^{1}$, Christel Weiss ${ }^{2}$, Frank A. Giordano ${ }^{1}$, Yasser Abo-Madyan ${ }^{1}$, \\ Benjamin Tuschy ${ }^{3}$, Marc Sütterlin ${ }^{3}$, Frederik Wenz ${ }^{4}$, Elena Sperk ${ }^{1}$ \\ ${ }^{1}$ Department of Radiation Oncology, ${ }^{2}$ Department of Clinical Statistics, Biomathematics, Information Processing, ${ }^{3}$ Department of Gynecology \\ and Obstetrics, Universitätsmedizin Mannheim, Medical Faculty Mannheim, Heidelberg University, Mannheim, Germany; ${ }^{4}$ Universitätsklinikum \\ Freiburg, Freiburg, Germany \\ Contributions: (I) Conception and design: All authors; (II) Administrative support: All authors; (III) Provision of study materials or patients: FA \\ Giordano, Y Abo-Madyan, B Tuschy, M Sütterlin, F Wenz, E Sperk; (IV) Collection and assembly of data: All authors; (V) Data analysis and \\ interpretation: C Wersal, C Weiss, FA Giordano, Y Abo-Madyan, B Tuschy, M Sütterlin, F Wenz, E Sperk; (VI) Manuscript writing: All authors; (VII) \\ Final approval of manuscript: All authors. \\ Correspondence to: Elena Sperk, MD. Department of Radiation Oncology, Strahlentherapie Haus 4, Ebene 0, Universitätsmedizin Mannheim, Medical \\ Faculty Mannheim, Heidelberg University, Theodor-Kutzer-Ufer 1-3, 68167 Mannheim, Germany. Email: elena.sperk@umm.de.
}

Background: Intraoperative radiotherapy (IORT) for breast cancer is used as an upfront boost or as accelerated partial breast irradiation (APBI). To date, no description of blood count changes after IORT are available. Our analysis shows blood count changes in breast cancer patients up to 5 years after IORT \pm whole breast radiotherapy (WBRT).

Methods: IORT was given as APBI in 58 patients (IORT/APBI-group) and as a boost in 198 patients (IORT/WBRT-group). A median dose of 20 Gy was given intraoperatively with low energy X-rays [INTRABEAM (TM) System] and additionally 46 Gy/2 Gy per fraction to the whole breast, if WBRT was added. Blood counts were collected preoperatively, after 90 days and through year 1-5 of followup. Dunnett's tests were used to calculate changes in blood counts over time. Additionally, platelet-tolymphocyte ratio (PLR), neutrophil-to-lymphocyte ratio (NLR) and derived neutrophil-to-lymphocyte ratio (dNLR) were calculated for each time point.

Results: Significantly decreases in the IORT/WBRT-group were seen for erythrocytes, hemoglobin, platelets and leucocytes and an increase for lymphocytes for the total follow-up period. In the IORT/APBIgroup significantly decreases were seen for erythrocytes and hemoglobin for the total follow-up period. Regarding changes during follow-up compared to the preoperative value, much more significant changes were seen in the IORT/WBRT-group compared to IORT/APBI-group without any relevant impact of chemotherapy. Regarding PLR-, NLR- and dNLR-values the rate of patients over the range improved over time in both groups.

Conclusions: IORT/APBI seems to have a smaller effect on blood counts compared to IORT/WBRT. Furthermore, PLR-, NLR- and dNLR-values improved over time, suggesting a positive effect on outcome after IORT in general.

Keywords: Intraoperative radiotherapy (IORT); whole breast radiotherapy (WBRT); accelerated partial breast irradiation (APBI); blood counts; breast cancer

Submitted Mar 25, 2019. Accepted for publication Aug 26, 2019.

doi: $10.21037 /$ tcr.2019.09.05

View this article at: http://dx.doi.org/10.21037/tcr.2019.09.05 


\section{Introduction}

Breast cancer is not only the most common tumor worldwide, but also the most common malignancy-related cause of death (1). The standard treatment of primary breast cancer consists of breast conserving surgery (BCS) followed by whole breast radiotherapy (WBRT) and, when indicated, an additional boost to the tumor bed. Over the past years, various procedures for accelerated partial breast irradiation (APBI) were developed, which can be used as advanced boost or sole radiotherapy to reduce or even replace postoperative whole breast irradiation (WBI). One of these procedures is intraoperative radiotherapy (IORT), in which the tumor bed only is irradiated directly after tumor resection using, e.g., a miniaturized X-ray source.

Radiotherapy can result in acute and chronic side effects. Changes in blood cell count, usually in the form of decreased cell numbers, can occur (2). The different blood cells (leucocytes, erythrocytes, and platelets) can all interact with carcinomas in one way or another $(3,4)$. Preoperative changes in blood parameters show predictive relevance for survival and absence of recurrence concerning different tumor entities (5-7). Especially, platelet-to-lymphocyte ratio (PLR), neutrophil-tolymphocyte ratio (NLR) and derived neutrophil-tolymphocyte ratio (dNLR) were associated with prognosis (8-11). An additional change of blood counts due to therapeutic irradiation could have further negative effects. The degree of side effects caused by radiotherapy depends on several factors, including the total dose applied and the irradiated volume. In contrast to WBRT, usually given in 1.8-2.0 Gy per fraction over 5-6 weeks during 5 days per week to the whole breast, only a single dose of 20 Gy to a small volume is applied during IORT (12). This means, that after IORT, the fractionation effect is absent so anticancer effects of leucocytes and other immunological effects can take place in the surrounding tissue immediately after irradiation $(13,14)$. Therefore, cumulative irradiated volume hosting blood cells in IORT is smaller, which might result in less changes of blood cell counts (Figure 1). To date, there are no longitudinal analyses on changes of blood cell counts following IORT for breast cancer.

The aim of this analysis was to determine the impact of IORT on the different blood parameters over a period of 5 years after irradiation, and to evaluate whether there are differences between IORT as APBI and IORT as an advanced boost with subsequent WBRT.

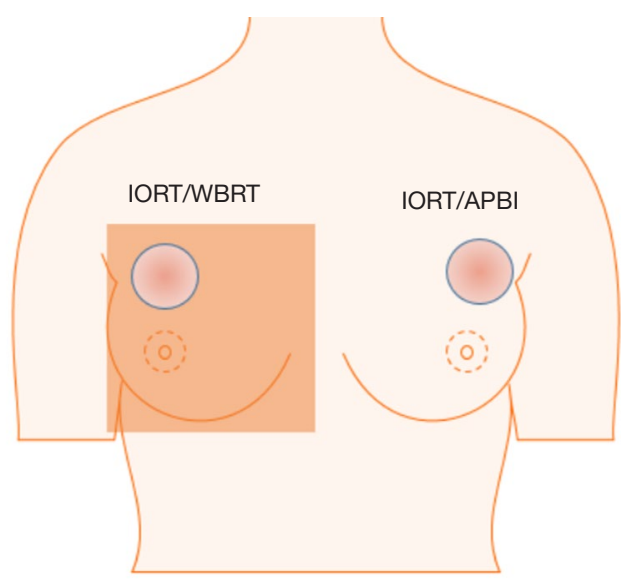

Figure 1 Irradiated volume during WBRT and IORT. WBRT is given in several fractions in a greater volume compared to IORT given as a single shot. In the IORT/WBRT-group both, WBRT and IORT, were applied, whereas in the IORT/APBIgroup only the small IORT volume was irradiated. WBRT, whole breast radiotherapy; IORT, intraoperative radiotherapy; APBI, accelerated partial breast irradiation.

\section{Methods}

\section{Patients}

Between 2008 and 2013, 256 breast cancer patients at the age of 26-90 years were treated with IORT as part of BCS. In 198 cases, IORT was used as an upfront boost with 12-20 Gy in combination with WBRT with 45-56 Gy (IORT/WBRT-group). In 58 cases, IORT was used as sole APBI with 12-20 Gy (IORT/APBI). Some patients were treated within the prospective studies TARGIT A, TARGIT E (lderly), and TARGIT boost quality registry (BQR). Ten patients received neoadjuvant chemotherapy, 85 patients received adjuvant chemotherapy, 194 patients received endocrine therapy, 26 patients received Trastuzumab therapy, and 11 patients received bisphosphonate therapy (Table 1). All patients approved the informed consent and the current analysis was also approved by the institutional review board (application number: 2016-866R-MA).

\section{Tecbnique}

IORT is given with a miniaturized $\mathrm{X}$-ray source (INTRABEAM ${ }^{\circledR}$-System, Carl Zeiss Meditec AG, Oberkochen, Germany), which emits low-energy X-rays (maximum energy $50 \mathrm{kV}$ ). Spherical applicators with 
Table 1 Patient and treatment characteristics

\begin{tabular}{|c|c|c|c|c|}
\hline Characteristics & Total patients $(n=256)$ & $\begin{array}{l}\text { IORT/WBRT-group } \\
\qquad(\mathrm{n}=198)\end{array}$ & $\begin{array}{l}\text { IORT/APBI-group } \\
\qquad(n=58)\end{array}$ & $P$ value \\
\hline \multicolumn{5}{|l|}{ General } \\
\hline Neoadjuvant chemotherapy, n (\%) & & & & 0.1228 (Fisher) \\
\hline No & $246(96.1)$ & $188(95.0)$ & $58(100.0)$ & \\
\hline Study, n (\%) & & & & $<0.0001\left(\mathrm{Chi}^{2}\right)$ \\
\hline TARGIT A & $39(15.2)$ & $25(12.6)$ & $14(24.1)$ & \\
\hline TARGIT E & $25(9.8)$ & $16(8.1)$ & $9(15.5)$ & \\
\hline \multicolumn{5}{|l|}{ Operation } \\
\hline Performance status, n (\%) & & & & 0.2162 (Fisher) \\
\hline 0 & $247(96.5)$ & $193(97.5)$ & $54(93.1)$ & \\
\hline 1 & $4(1.6)$ & $2(1.0)$ & $2(3.4)$ & \\
\hline Unknown & $5(2.0)$ & $3(1.5)$ & $2(3.4)$ & \\
\hline \multicolumn{5}{|l|}{ Tumor characteristics } \\
\hline Localization, n (\%) & & & & - \\
\hline Ductal invasive & $210(82.0)$ & $159(80.3)$ & $51(87.9)$ & \\
\hline Tubulo-lobular/invasive & $34(13.3)$ & $31(15.7)$ & $3(5.2)$ & \\
\hline Mucinous & $6(2.3)$ & $4(2.0)$ & $2(3.5)$ & \\
\hline Tubular invasive & $3(1.2)$ & $2(1.0)$ & $1(1.7)$ & \\
\hline Medullar & $2(0.8)$ & $2(1.0)$ & 0 & \\
\hline DCIS & $1(0.4)$ & 0 & $1(1.7)$ & \\
\hline Grading, n (\%) & & & & $0.1017\left(\mathrm{Chi}^{2}\right)$ \\
\hline 1 & $42(16.4)$ & 38 (19.2) & $4(6.9)$ & \\
\hline 2 & 149 (58.2) & $112(56.6)$ & 37 (63.8) & \\
\hline 3 & $56(21.9)$ & $43(21.7)$ & $13(22.4)$ & \\
\hline Unknown & $9(3.5)$ & $5(2.5)$ & $4(6.9)$ & \\
\hline
\end{tabular}

Table 1 (continued) 
Table 1 (continued)

\begin{tabular}{|c|c|c|c|c|}
\hline Characteristics & Total patients $(n=256)$ & $\begin{array}{l}\text { IORT/WBRT-group } \\
\qquad(\mathrm{n}=198)\end{array}$ & $\begin{array}{l}\text { IORT/APBI-group } \\
(\mathrm{n}=58)\end{array}$ & $P$ value \\
\hline T stage, n (\%) & & & & 0.0406 (Fisher) \\
\hline 1 & $2(0.8)$ & $2(1.0)$ & 0 & \\
\hline $1 c$ & $135(52.7)$ & $103(52.0)$ & $32(55.2)$ & \\
\hline 2 & $44(17.2)$ & $40(20.2)$ & $4(6.9)$ & \\
\hline is & $1(0.4)$ & 0 & $1(1.7)$ & \\
\hline 1 & $2(0.8)$ & $1(0.5)$ & $1(1.7)$ & \\
\hline $1 \mathrm{mi}$ & $5(2.0)$ & $4(2.0)$ & $1(1.7)$ & \\
\hline $1 a$ & $30(11.7)$ & $28(14.1)$ & $2(3.4)$ & \\
\hline 2 & $1(0.4)$ & $1(0.5)$ & 0 & \\
\hline $2 a$ & $6(2.3)$ & $5(2.5)$ & $1(1.7)$ & \\
\hline 3 & $1(0.4)$ & $1(0.5)$ & 0 & \\
\hline $3 a$ & $2(0.8)$ & $2(1.0)$ & 0 & \\
\hline L stage, n (\%) & & & & $0.0733\left(\mathrm{Chi}^{2}\right)$ \\
\hline 0 & $184(71.9)$ & $138(69.7)$ & $46(79.3)$ & \\
\hline 1 & $59(23.0)$ & $51(25.8)$ & $8(13.8)$ & \\
\hline$x$ & $13(5.1)$ & $9(4.5)$ & $4(6.9)$ & \\
\hline V stage, n (\%) & & & & 0.6881 (Fisher) \\
\hline 0 & $233(91.0)$ & $181(91.4)$ & $52(89.7)$ & \\
\hline 1 & $9(3.5)$ & $8(4.0)$ & $1(1.7)$ & \\
\hline$x$ & $14(5.5)$ & $9(4.5)$ & $5(8.6)$ & \\
\hline
\end{tabular}

Table 1 (continued) 
Table 1 (continued)

\begin{tabular}{|c|c|c|c|c|}
\hline Characteristics & Total patients $(n=256)$ & $\begin{array}{l}\text { IORT/WBRT-group } \\
\qquad(n=198)\end{array}$ & $\begin{array}{l}\text { IORT/APBI-group } \\
\qquad(\mathrm{n}=58)\end{array}$ & $P$ value \\
\hline Estrogen receptor, n (\%) & & & & $0.2502\left(\mathrm{Chi}^{2}\right)$ \\
\hline Negative & $37(14.5)$ & $26(13.1)$ & $11(19.0)$ & \\
\hline Positive & $198(77.3)$ & $156(78.8)$ & $42(72.4)$ & \\
\hline Negative & $55(21.5)$ & $40(20.2)$ & $15(25.9)$ & \\
\hline Unknown & $3(1.2)$ & $2(1.0)$ & $1(1.7)$ & \\
\hline \multirow[t]{2}{*}{ Applicator size (cm) } & Mean: 4.1 & Mean: 4.1 & Mean: 4.2 & 0.2461 (u-test) \\
\hline & Median: 4.0 [2.5-5.0] & Median: 4.0 [2.5-5.0] & Median: $4.0[3.0-5.0]$ & \\
\hline \multirow[t]{2}{*}{ IORT time (min) } & Mean: 31.8 & Mean: 31.6 & Mean: 32.8 & 0.4793 ( $t$-test) \\
\hline & Median: 28 [12-53] & Median: 28 [12-53] & Median: 28 [18-52] & \\
\hline \multicolumn{5}{|l|}{ WBRT-data } \\
\hline \multirow[t]{2}{*}{ Days between BCS and WBRT } & - & Mean: 97.8 & - & - \\
\hline & & Median: 55 [22-307] & & \\
\hline Chemotherapy & & & & $<0.0001\left(\mathrm{Chi}^{2}\right)$ \\
\hline No & $169(66.0)$ & $118(59.6)$ & $51(87.9)$ & \\
\hline Yes & $85(33.2)$ & $79(39.9)$ & $6(10.3)$ & \\
\hline Unknown & $2(0.8)$ & $1(0.5)$ & $1(1.7)$ & \\
\hline Hormone therapy, n (\%) & & & & 0.0029 (Fisher) \\
\hline Tamoxifen & $100(39)$ & $86(43.4)$ & $14(24.1)$ & \\
\hline $\mathrm{Al}$ & $53(20.7)$ & $39(19.7)$ & $14(24.1)$ & \\
\hline Tamoxifen + Al & 40 (15.6) & $33(16.7)$ & 7 (12.1) & \\
\hline Faslodex & $1(0.4)$ & $1(0.5)$ & 0 & \\
\hline No therapy & 55 (21.5) & $32(16.2)$ & $23(39.7)$ & \\
\hline Unknown & $7(2.7)$ & $7(3.5)$ & 0 & \\
\hline
\end{tabular}

Table 1 (continued) 
Table 1 (continued)

\begin{tabular}{lccc}
\hline Characteristics & Total patients $(\mathrm{n}=256)$ & $\begin{array}{c}\text { IORT/WBRT-group } \\
(\mathrm{n}=198)\end{array}$ & $\begin{array}{c}\text { IORT/APBI-group } \\
(\mathrm{n}=58)\end{array}$ \\
\hline Trastuzumab, $\mathrm{n}(\%)$ & $156(60.9)$ & $101(51.0)$ & $55(94.8)$ \\
No & $26(10.2)$ & $25(12.6)$ & $1(1.7)$ \\
Yes & $74(28.9)$ & $72(36.4)$ & $2(3.4)$ \\
Unknown & & $19013\left(\mathrm{Chi}^{2}\right)$ & $0.0194($ Fisher $)$ \\
Bisphosphonate, $\mathrm{n}(\%)$ & $244(95.3)$ & $52(89.7)$ \\
No & $11(4.3)$ & $5(2.5)$ & $6(10.3)$ \\
Yes & $1(0.4)$ & $1(0.5)$ & 0 \\
Unknown & & \\
\hline
\end{tabular}

WBRT, whole breast radiotherapy; IORT, intraoperative radiotherapy; $\mathrm{APBI}$, accelerated partial breast irradiation; $\mathrm{BQR}$, boost quality registry; DCIS, ductal carcinoma in situ; $\mathrm{BCS}$, breast conserving surgery; Al, aromatase inhibitor.

different diameters $(2.5-5.0 \mathrm{~cm})$ were used for homogenous irradiation of the tumor bed immediately after tumor resection for 12-53 minutes. Details using low energy $\mathrm{X}$-rays for IORT were published elsewhere (15).

WBRT was applied with dedicated linear accelerators using standard single fractions of 1.8-2.0 Gy per week up to 46.0-56.0 Gy treatment dose.

Systemic treatment was given according to current recommendations.

\section{Data collection}

Blood counts were measured preoperatively and during a 5 -year-follow-up period. Partial blood counts contained the parameters erythrocytes, hemoglobin, hematocrit, mean corpuscular volume (MCV), mean corpuscular hemoglobin $(\mathrm{MCH})$, mean corpuscular hemoglobin concentration (MCHC), platelets, and leucocytes. These were preoperatively available for all patients, 1-90 days after IORT for 214 patients, during the first year for 139 patients, during the second year for 86 patients, during the third year for 66 patients, during the fourth year for 51 patients, and during the fifth year for 35 patients. Furthermore, complete blood counts with neutrophils, lymphocytes, monocytes, eosinophils, and basophils were acquired. These were preoperatively available for nine patients, 1-90 days after IORT for 66 patients, during the first year for 87 patients, during the second year for 44 patients, during the third year for 36 patients, during the fourth year for 18 patients, and during the fifth year for 19 patients.

\section{Statistics}

Primary analysis was the analysis of variance of all measures over time for each radiotherapy type. Additionally, variance analysis in the form of Dunnett's-tests was performed for the IORT/APBI-group and the IORT/WBRT-group separately. Therefore, blood values were compared with their preoperative values and controlled for significant changes. Adjusted $\mathrm{P}$ values were calculated and considered significant for $\mathrm{P}<0.05$. Dunnett's-tests have several advantages over $t$-tests. For each parameter, a global $\mathrm{P}$ value is calculated, which shows changes over the total followup period. By adjusting $\mathrm{P}$ values, the 5\%-significance level can be ensured, although various single tests are performed. Finally, data analysis using variance analysis is more efficient than several $t$-tests, especially if sparse data is available as it is the case at the end of the follow-up period of this analysis.

The same analysis was performed for all patients without chemotherapy, to face a potential impact of chemotherapy on the results. This analysis was performed only for the partial blood count parameters as number of complete blood counts was very low in this group.

Besides, PLR-, NLR- and dNLR-values were calculated for each period and patients were assigned to the groups "below normal range" and "above normal range" for each period. The percentages of both groups were calculated and shown in a diagram over time. The normal range was determined considering several studies that showed a correlation between the ratios and the prognosis of tumor patients. The normal range for PLR was set to $185(10,16)$, 
for NLR to $4(8,11,17-19)$ and for dNLR to 2 (11).

\section{Results}

\section{White blood cells}

In the IORT/WBRT-group, significant changes in leucocyte counts could be seen during the total follow-up period. All postoperative values were below the preoperative value, but the value in the first year was the only one that decreased significantly.

In the IORT/APBI-group, no significant changes could be found (Table 2).

However, the patients without chemotherapy showed a significant increase of leucocyte values in the first 90 days after BCS/IORT in the IORT/WBRT-group. In the IORT/ APBI-group, no significant changes could be found (Table 3).

In the Dunnett's-tests, the only significant change in complete white blood counts was a significant increase of lymphocyte counts for the total follow-up period in the IORT/WBRT-group (Table 2).

\section{Red blood cells}

In the IORT/WBRT-group, significant declines of the erythrocyte counts were shown for the total follow-up period as well as for every single postoperative time point compared to the preoperative values and for the first ninety days as well as for the first, third and fifth year in hematocrit.

In the IORT/APBI-group there was a significant change in the total follow-up period as well as a decrease in the first year after BCS/IORT compared to the preoperative value (Table 2). The same changes were found in the analysis of hematocrit (not shown).

The analysis of the patients without adjuvant chemotherapy showed no significant changes in the IORT/ APBI-group for erythrocytes and hematocrit (Table 3).

Furthermore, there were significant changes of hemoglobin values in the IORT/WBRT-group during the total follow-up period as well as in the first 90 days, first year and fifth year after BCS/IORT.

In the IORT/APBI-group, significant changes of hemoglobin values were observed in the total follow-up period as well as an isolated decrease in the first year after BCS/IORT (Table 2).

In the analysis of the patients without chemotherapy, the same changes were found (Table 3).

Additionally, in the IORT/WBRT-group, significant changes of $\mathrm{MCV}, \mathrm{MCH}$ and $\mathrm{MCHC}$ could be seen during the total follow-up period. Compared to preoperative values, a significant increase of MCV values in the third year as well as of $\mathrm{MCH}$ values in the third and fourth year after BCS/IORT could be seen.

The same changes were found in the analysis of patients without chemotherapy. On the contrary, MCHC values showed a significant decrease instead of increase during the first 90 days and during the first year after BCS/IORT. In the analysis of patients without chemotherapy, only changes in the first 90 days were found.

In the IORT/APBI-group, no significant changes could be found for erythrocyte indices (not shown) in the total group as well as in the patients without chemotherapy.

\section{Platelets}

In the IORT/WBRT-group, significant changes of platelet counts were seen during the total follow-up period. Compared to preoperative values, significant decreases were found between the first and the fifth year after BCS/ IORT (Table 2). In the analysis of the patients without chemotherapy, significant changes could be found for the total follow-up period as well as for the first, second, fourth and fifth year after BCS/IORT (Table 3).

However, in the IORT/APBI-group, no significant change could be seen in the total group as well as in the patients without chemotherapy.

\section{Ratios}

\section{PLR}

Preoperative and until 90 days after IORT, more than half of the patients' PLR-values were below the normal range of 185 . During the first year, this percentage decreased and almost $60 \%$ of the patients were above the normal range. Afterwards, the percentage of patients below the normal range increased again and it leveled out between $65 \%$ and $80 \%$ (Figure 2).

\section{NLR}

More than half of the preoperative NLR-values were below the normal range of 4 . This percentage increased almost continuously after BCS/IORT and it leveled out between 
Table 2 Changes in blood counts in IORT/WBRT-group and IORT/APBI-group (Dunnett's-tests)

\begin{tabular}{|c|c|c|c|c|c|c|c|c|c|}
\hline Parameter & $\begin{array}{c}\text { Type of } \\
\text { radiotherapy }\end{array}$ & $\begin{array}{l}\text { Global } \\
\text { P value }\end{array}$ & Preoperative & 1-90 days & $1^{\text {st }}$ year & $2^{\text {nd }}$ year & $3^{\text {rd }}$ year & $4^{\text {th }}$ year & $5^{\text {th }}$ year \\
\hline \multirow[t]{6}{*}{$\begin{array}{l}\text { Erythrocytes } \\
(\mathrm{mil} / \mu \mathrm{L})\end{array}$} & IORT/WBRT & $<0.0001$ & $\begin{array}{c}4.5 \\
(S D, 0.36)\end{array}$ & $\begin{array}{c}4.3 \\
(\mathrm{SD}, 0.39)\end{array}$ & $\begin{array}{c}4.1 \\
(\mathrm{SD}, 0.38)\end{array}$ & $\begin{array}{c}4.3 \\
(\mathrm{SD}, 0.39)\end{array}$ & $\begin{array}{c}4.3 \\
(\mathrm{SD}, 0.46)\end{array}$ & $\begin{array}{c}4.3 \\
(\mathrm{SD}, 0.53)\end{array}$ & $\begin{array}{c}4.3 \\
(\mathrm{SD}, 0.41)\end{array}$ \\
\hline & $P$ value & & - & $<0.0001$ & $<0.0001$ & 0.0015 & 0.0002 & 0.0024 & 0.0068 \\
\hline & $\begin{array}{l}\text { Patients at } \\
\text { risk }\end{array}$ & & 198 & 181 & 120 & 70 & 52 & 41 & 26 \\
\hline & IORT/APBI & 0.0357 & $\begin{array}{c}4.5 \\
(\mathrm{SD}, 0.51)\end{array}$ & $\begin{array}{c}4.3 \\
(\mathrm{SD}, 0.48)\end{array}$ & $\begin{array}{c}4.2 \\
(\mathrm{SD}, 0.61)\end{array}$ & $\begin{array}{c}4.2 \\
(\mathrm{SD}, 0.73)\end{array}$ & $\begin{array}{c}4.5 \\
(\mathrm{SD}, 0.64)\end{array}$ & $\begin{array}{c}4.3 \\
(\mathrm{SD}, 0.56)\end{array}$ & $\begin{array}{c}4.3 \\
(\mathrm{SD}, 0.61)\end{array}$ \\
\hline & $P$ value & & - & 0.4131 & 0.0064 & 0.1149 & 0.9748 & 0.9691 & 0.9986 \\
\hline & $\begin{array}{l}\text { Patients at } \\
\text { risk }\end{array}$ & & 58 & 33 & 19 & 16 & 14 & 10 & 8 \\
\hline \multirow{5}{*}{$\begin{array}{l}\text { Hemoglobin } \\
\text { (g/dL) }\end{array}$} & $P$ value & & - & $<0.0001$ & $<0.0001$ & 0.0584 & 0.0949 & 0.0908 & 0.0259 \\
\hline & $\begin{array}{l}\text { Patients at } \\
\text { risk }\end{array}$ & & 198 & 181 & 120 & 70 & 52 & 41 & 26 \\
\hline & IORT/APBI & 0.0055 & $\begin{array}{c}13.3 \\
(\mathrm{SD}, 1.52)\end{array}$ & $\begin{array}{c}12.6 \\
(\mathrm{SD}, 1.32)\end{array}$ & $\begin{array}{c}12.1 \\
(\mathrm{SD}, 1.58)\end{array}$ & $\begin{array}{c}12.3 \\
(\mathrm{SD}, 2.13)\end{array}$ & $\begin{array}{c}13.1 \\
(\mathrm{SD}, 1.53)\end{array}$ & $\begin{array}{c}12.8 \\
(\mathrm{SD}, 1.50)\end{array}$ & $\begin{array}{c}12.8 \\
(\mathrm{SD}, 1.70)\end{array}$ \\
\hline & $P$ value & & - & 0.1211 & 0.0008 & 0.0633 & 0.9623 & 0.9006 & 0.9911 \\
\hline & $\begin{array}{l}\text { Patients at } \\
\text { risk }\end{array}$ & & 58 & 33 & 19 & 16 & 14 & 10 & 8 \\
\hline \multirow[t]{3}{*}{$\begin{array}{l}\text { Platelets } \\
(/ \mathrm{nL})\end{array}$} & IORT/WBRT & $<0.0001$ & $\begin{array}{c}262 \\
(\mathrm{SD}, 61.63)\end{array}$ & $\begin{array}{c}263 \\
(\mathrm{SD}, 77.90)\end{array}$ & $\begin{array}{c}248 \\
(\mathrm{SD}, 71.43)\end{array}$ & $\begin{array}{c}239 \\
(\mathrm{SD}, 65.54)\end{array}$ & $\begin{array}{c}237 \\
(\mathrm{SD}, 55.34)\end{array}$ & $\begin{array}{c}229 \\
(\mathrm{SD}, 70.06)\end{array}$ & $\begin{array}{c}236 \\
(\mathrm{SD}, 76.62)\end{array}$ \\
\hline & $P$ value & & - & 0.9971 & 1.0000 & 0.9939 & 0.8922 & 0.4786 & 0.9877 \\
\hline & $\begin{array}{l}\text { Patients at } \\
\text { risk }\end{array}$ & & 58 & 33 & 19 & 16 & 14 & 10 & 8 \\
\hline \multirow[t]{6}{*}{$\begin{array}{l}\text { Leucocytes } \\
\text { (/nL) }\end{array}$} & IORT/WBRT & 0.0047 & $\begin{array}{c}7.1 \\
(\mathrm{SD}, 2.19)\end{array}$ & $\begin{array}{c}6.9 \\
(\mathrm{SD}, 2.73)\end{array}$ & $\begin{array}{c}6.3 \\
(\mathrm{SD}, 2.93)\end{array}$ & $\begin{array}{c}6.7 \\
(\mathrm{SD}, 3.04)\end{array}$ & $\begin{array}{c}6.4 \\
(\mathrm{SD}, 1.82)\end{array}$ & $\begin{array}{c}6.4 \\
(\mathrm{SD}, 1.97)\end{array}$ & $\begin{array}{c}6.2 \\
(\mathrm{SD}, 1.89)\end{array}$ \\
\hline & $P$ value & & - & 0.4750 & 0.0002 & 0.4666 & 0.2624 & 0.7078 & 0.6252 \\
\hline & $\begin{array}{l}\text { Patients at } \\
\text { risk }\end{array}$ & & 198 & 181 & 120 & 70 & 52 & 40 & 26 \\
\hline & IORT/APBI & 0.2349 & $\begin{array}{c}7.2 \\
(\mathrm{SD}, 1.92)\end{array}$ & $\begin{array}{c}8.0 \\
(S D, 3.62)\end{array}$ & $\begin{array}{c}6.5 \\
(\mathrm{SD}, 2.65)\end{array}$ & $\begin{array}{c}6.8 \\
(\mathrm{SD}, 2.54)\end{array}$ & $\begin{array}{c}6.2 \\
(\mathrm{SD}, 1.93)\end{array}$ & $\begin{array}{c}5.6 \\
(\mathrm{SD}, 1.04)\end{array}$ & $\begin{array}{c}6.5 \\
(S D, 1.91)\end{array}$ \\
\hline & $P$ value & & - & 0.2162 & 0.9694 & 0.9989 & 0.9954 & 0.9783 & 0.9964 \\
\hline & $\begin{array}{l}\text { Patients at } \\
\text { risk }\end{array}$ & & 58 & 33 & 19 & 16 & 14 & 10 & 8 \\
\hline
\end{tabular}

Table 2 (continued) 
Table 2 (continued)

\begin{tabular}{|c|c|c|c|c|c|c|c|c|c|}
\hline Parameter & $\begin{array}{c}\text { Type of } \\
\text { radiotherapy }\end{array}$ & $\begin{array}{l}\text { Global } \\
\text { P value }\end{array}$ & Preoperative & $1-90$ days & $1^{\text {st }}$ year & $2^{\text {nd }}$ year & $3^{\text {rd }}$ year & $4^{\text {th }}$ year & $5^{\text {th }}$ year \\
\hline \multirow[t]{6}{*}{$\begin{array}{l}\text { Lymphocytes } \\
\text { (\%) }\end{array}$} & IORT/WBRT & 0.0037 & $\begin{array}{c}19.0 \\
(\mathrm{SD}, 7.42)\end{array}$ & $\begin{array}{c}29.8 \\
(\mathrm{SD}, 15.08)\end{array}$ & $\begin{array}{c}22.6 \\
(\mathrm{SD}, 11.27)\end{array}$ & $\begin{array}{c}23.3 \\
(\mathrm{SD}, 12.17)\end{array}$ & $\begin{array}{c}24.8 \\
(\mathrm{SD}, 6.65)\end{array}$ & $\begin{array}{c}26.9 \\
(\mathrm{SD}, 10.23)\end{array}$ & $\begin{array}{c}26.0 \\
(\mathrm{SD}, 7.71)\end{array}$ \\
\hline & $P$ value & & - & 0.0996 & 0.9811 & 0.5604 & 0.6891 & 0.5034 & 0.4014 \\
\hline & $\begin{array}{l}\text { Patients at } \\
\text { risk }\end{array}$ & & 7 & 63 & 82 & 37 & 29 & 14 & 12 \\
\hline & IORT/APBI & 0.6873 & $\begin{array}{c}36.5 \\
(\mathrm{SD}, 18.17)\end{array}$ & $\begin{array}{c}15.6 \\
(\mathrm{SD}, 11.09)\end{array}$ & $\begin{array}{c}26.6 \\
(\mathrm{SD}, 16.33)\end{array}$ & $\begin{array}{c}27.9 \\
(\mathrm{SD}, 7.02)\end{array}$ & $\begin{array}{c}23.5 \\
(\mathrm{SD}, 8.57)\end{array}$ & $\begin{array}{c}27.0 \\
(\mathrm{SD}, 4.69)\end{array}$ & $\begin{array}{c}26.7 \\
(\mathrm{SD}, 8.66)\end{array}$ \\
\hline & $P$ value & & - & 0.2627 & 0.4193 & 0.5139 & 0.3371 & 0.5107 & 0.5427 \\
\hline & $\begin{array}{l}\text { Patients at } \\
\text { risk }\end{array}$ & & 2 & 3 & 5 & 7 & 7 & 4 & 7 \\
\hline
\end{tabular}

Global $\mathrm{P}$ value, change for the total follow-up period; SD, standard deviation; WBRT, whole breast radiotherapy; IORT, intraoperative radiotherapy; $\mathrm{APBI}$, accelerated partial breast irradiation.

Table 3 Changes in blood counts in IORT/WBRT-group and IORT/APBI-group (Dunnett's-tests) in patients without chemotherapy only

\begin{tabular}{|c|c|c|c|c|c|c|c|c|c|}
\hline Parameter & Type of radiotherapy & $\begin{array}{l}\text { Global } \\
\text { P value }\end{array}$ & Preoperative & $1-90$ days & $1^{\text {st }}$ year & $2^{\text {nd }}$ year & $3^{\text {rd }}$ year & $4^{\text {th }}$ year & $5^{\text {th }}$ year \\
\hline \multirow{3}{*}{$\begin{array}{l}\text { Erythrocytes } \\
\text { (mil/ } / \mathrm{L})\end{array}$} & IORT/WBRT & $<0.0001$ & 4.5 & 4.4 & 4.3 & 4.3 & 4.2 & 4.2 & 4.2 \\
\hline & IORT/APBI & 0.2201 & 4.5 & 4.3 & 4.3 & 4.3 & 4.6 & 4.4 & 4.5 \\
\hline & $P$ value & & - & 0.4290 & 0.1395 & 0.2643 & 1.0000 & 0.9282 & 0.9996 \\
\hline \multirow{3}{*}{$\begin{array}{l}\text { Hemoglobin } \\
(\mathrm{g} / \mathrm{dL})\end{array}$} & $P$ value & & - & 0.0001 & 0.0051 & 0.5660 & 0.1301 & 0.4166 & 0.0329 \\
\hline & IORT/APBI & 0.1075 & 13.3 & 12.5 & 12.3 & 12.5 & 13.3 & 13.2 & 13.2 \\
\hline & $P$ value & & - & 0.1802 & 0.0465 & 0.2158 & 0.9891 & 0.9543 & 0.9944 \\
\hline $\begin{array}{l}\text { Platelets } \\
(/ \mathrm{nL})\end{array}$ & $P$ value & & - & 0.9934 & 0.9998 & 0.9850 & 0.5978 & 0.9474 & 1.0000 \\
\hline \multirow{4}{*}{$\begin{array}{l}\text { Leucocytes } \\
(/ \mathrm{nL})\end{array}$} & IORT/WBRT & 0.1694 & 7.1 & 7.1 & 6.5 & 6.6 & 6.4 & 6.1 & 6.6 \\
\hline & $P$ value & & - & 1 & 0.0788 & 0.3170 & 0.9025 & 0.8934 & 0.9993 \\
\hline & IORT/APBI & 0.1598 & 7.1 & 8.3 & 6.8 & 7.1 & 6.5 & 5.2 & 6.5 \\
\hline & $P$ value & & - & 0.0451 & 1.0000 & 0.9994 & 0.9995 & 0.9965 & 0.9999 \\
\hline
\end{tabular}

Global P value, change for the total follow-up period; WBRT, whole breast radiotherapy; IORT, intraoperative radiotherapy; APBI, accelerated partial breast irradiation. 


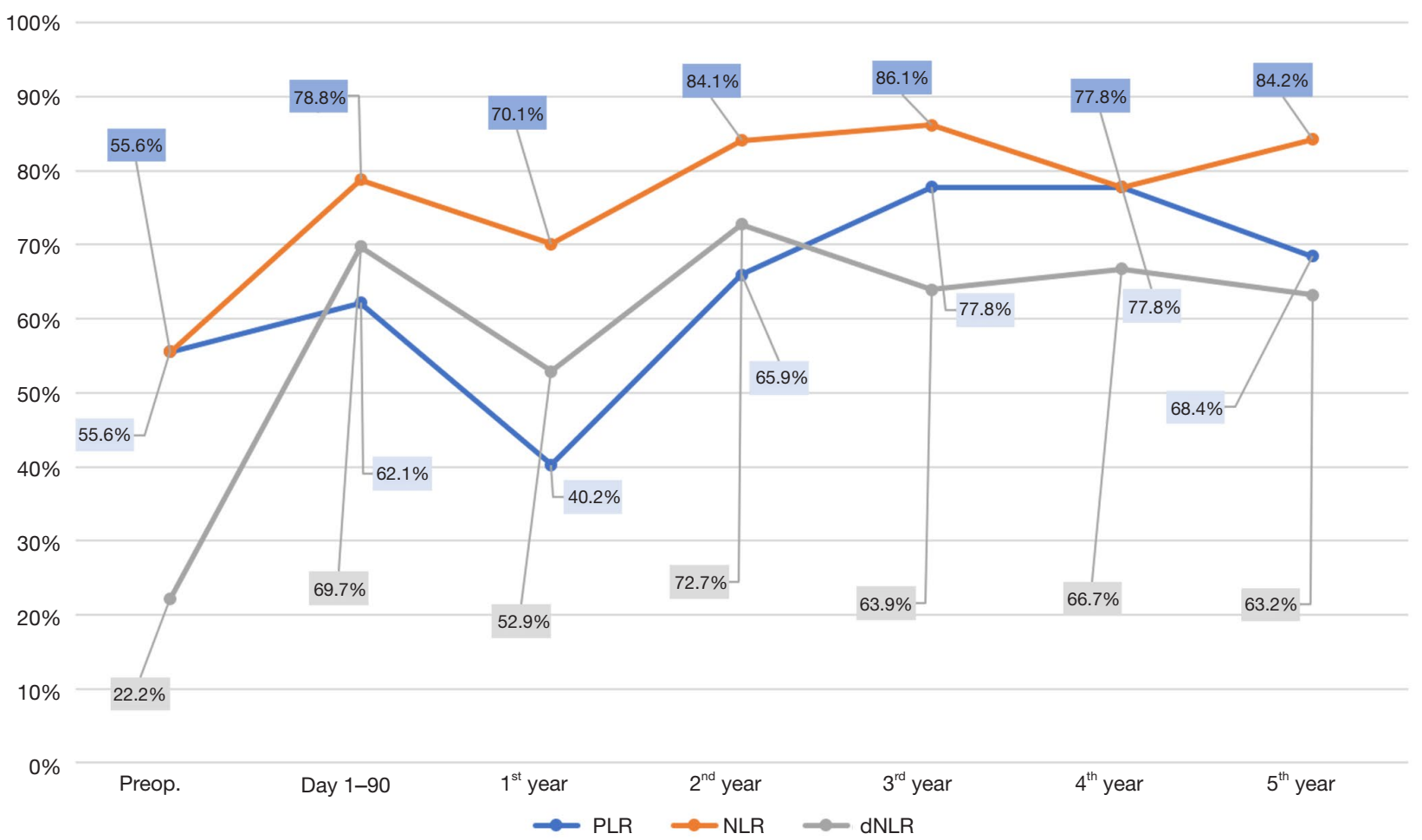

Figure 2 Percentage of patients with a NLR (normal range 4), PLR (normal range 185), dNLR (normal range 2) below normal range over time. NLR, neutrophil-to-lymphocyte ratio; PLR, platelet-to-lymphocyte ratio; dNLR, derived neutrophil-to-lymphocyte ratio.

$77 \%$ and $87 \%$ (Figure 2).

\section{dNLR}

Preoperatively, almost $80 \%$ of dNLR-values were above the normal range of 2. During the first 90 days, there was a steep increase of patients below the normal range. After a temporary decrease of this percentage during the first year, it leveled out between $63 \%$ and $73 \%$ (Figure 2).

\section{Discussion}

In the IORT/WBRT-group of the current analysis, significant changes of erythrocytes, platelets, and leucocytes could be observed during a follow-up of 5 years. In contrast, significant changes in the IORT/APBI-group could only be observed temporarily for the red blood cells (Figure 3). In the analysis of the patients without chemotherapy, significant changes were also more often in the IORT/WBRT-group compared to the IORT/APBI-group. This is the first longitudinal long-term description of blood cell counts after BCS/IORT and the first comparison of IORT/APBI $v s$. IORT/WBRT. The degree of side effects on blood and other organs due to radiotherapy depends on different biological, physical, physiological and individual factors (20). The effect of external radiotherapy of the breast and other organs on different blood parameters was content of several studies, however, many of those studies had follow-up periods of only a few weeks. A summary of several of these studies is shown in Table 4.

\section{Red blood cells}

Multiple studies showed changes of red blood cell counts after radiotherapy $(2,24,29,30)$. In the current analysis significant changes could be seen especially in the IORT/ WBRT-group. Erythrocytes and hematocrit were decreased significantly in the whole follow-up period, hemoglobin was decreased significantly at the beginning and at the end of the follow-up period. The changes in erythrocyte indices indicate radiotherapy to have an effect on morphology and content of erythrocytes as well. Other studies could not find changes in red blood cells after radiotherapy at all $(28,32,34)$ or changes were normalized after only a few weeks $(24,30)$. 


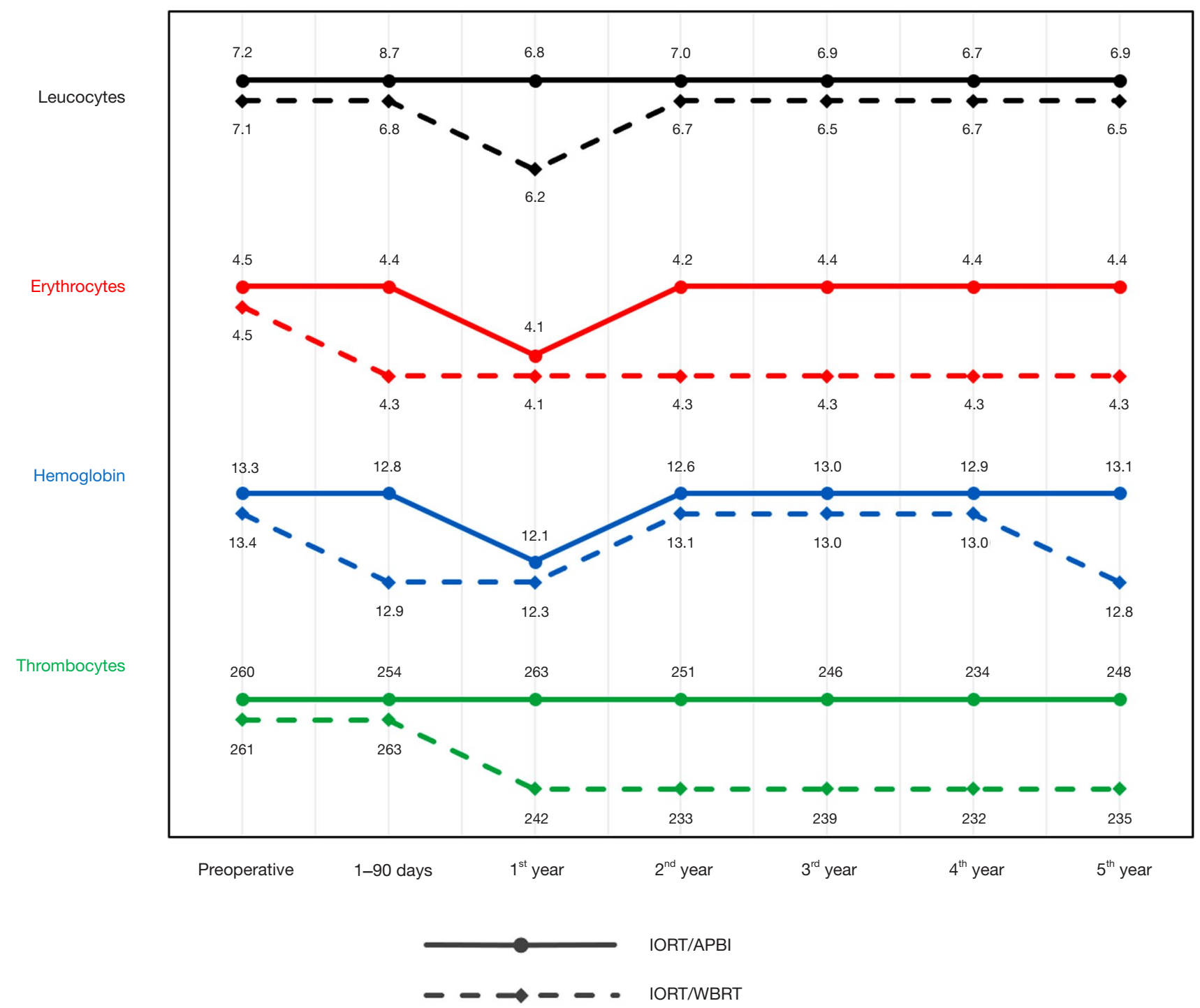

Figure 3 Blood count changes during a follow-up of 5 years after IORT/APBI and IORT/WBRT. WBRT, whole breast radiotherapy; IORT, intraoperative radiotherapy; APBI, accelerated partial breast irradiation.

In contrast to the IORT/WBRT-group, significant changes of red blood cells in the IORT/APBI-group were only temporary within the first year after IORT and showed a better recovery during follow-up compared to the IORT/ WBRT-group. This is in line with the results of Shahid et al. who showed that the extent of the decrease of erythrocytes depends on the delivered dose (2).

Erythrocytes and hemoglobin are responsible for oxygen transport. Gao et al. showed that patients with anemia during or after radiotherapy had a significantly worse prognosis (4). Anemic conditions can cause tumor hypoxia, which leads to reduced radiosensibility of tumors (35). Furthermore, hypoxic tumors can release various substances like hypoxia-inducible factor 1 (HIF-1), that can enhance malignant behavior of tumor cells (36). In some studies, the treatment of anemia for patients with breast cancer did not influence survival and recurrence $(37,38)$. However, Zhang et al. could show that preoperative anemia is an independent prognostic factor for survival and absence of recurrence (39). Therefore, IORT as APBI could have an advantage over WBRT due to its lower influence on red blood cells. 


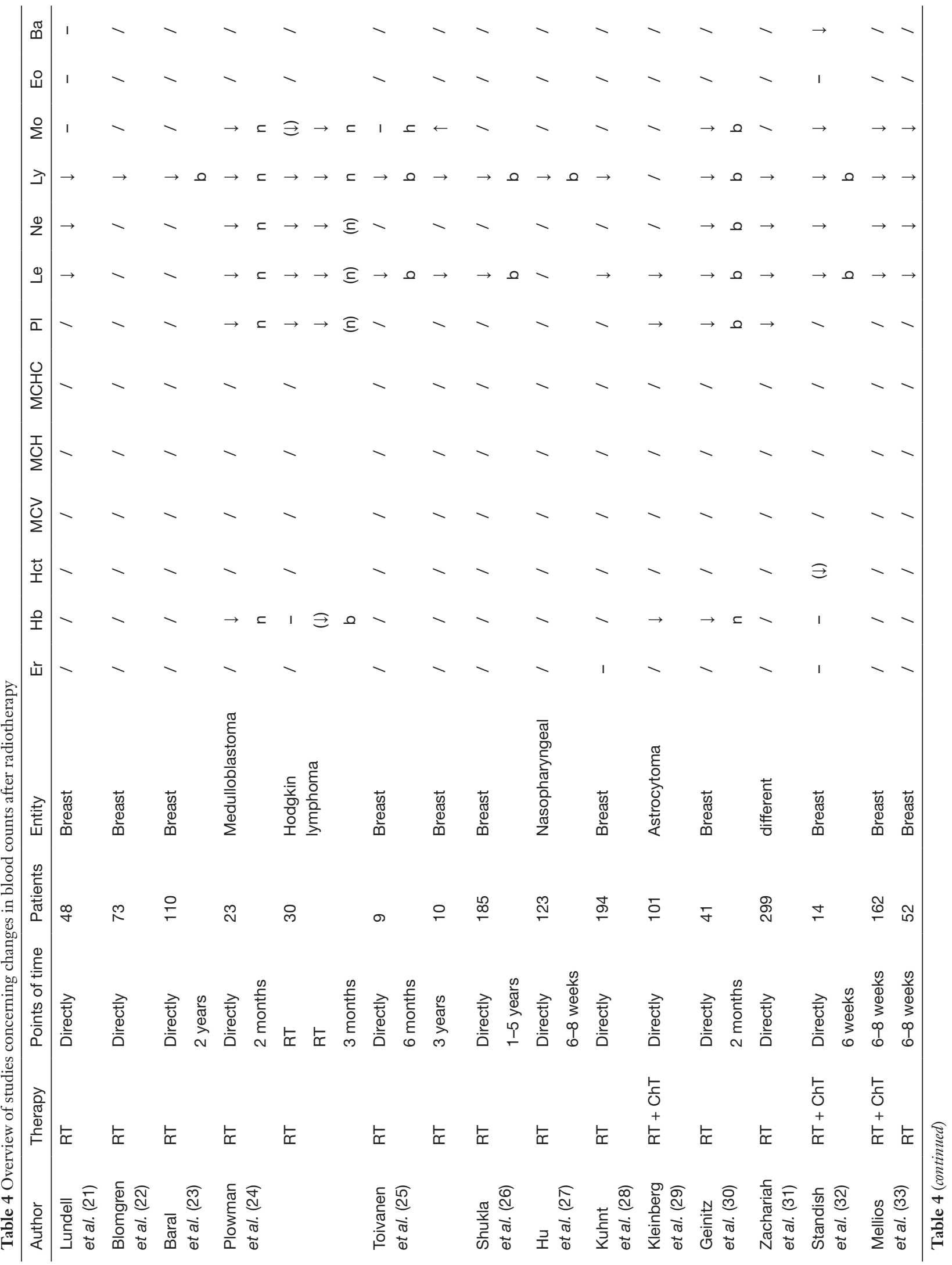




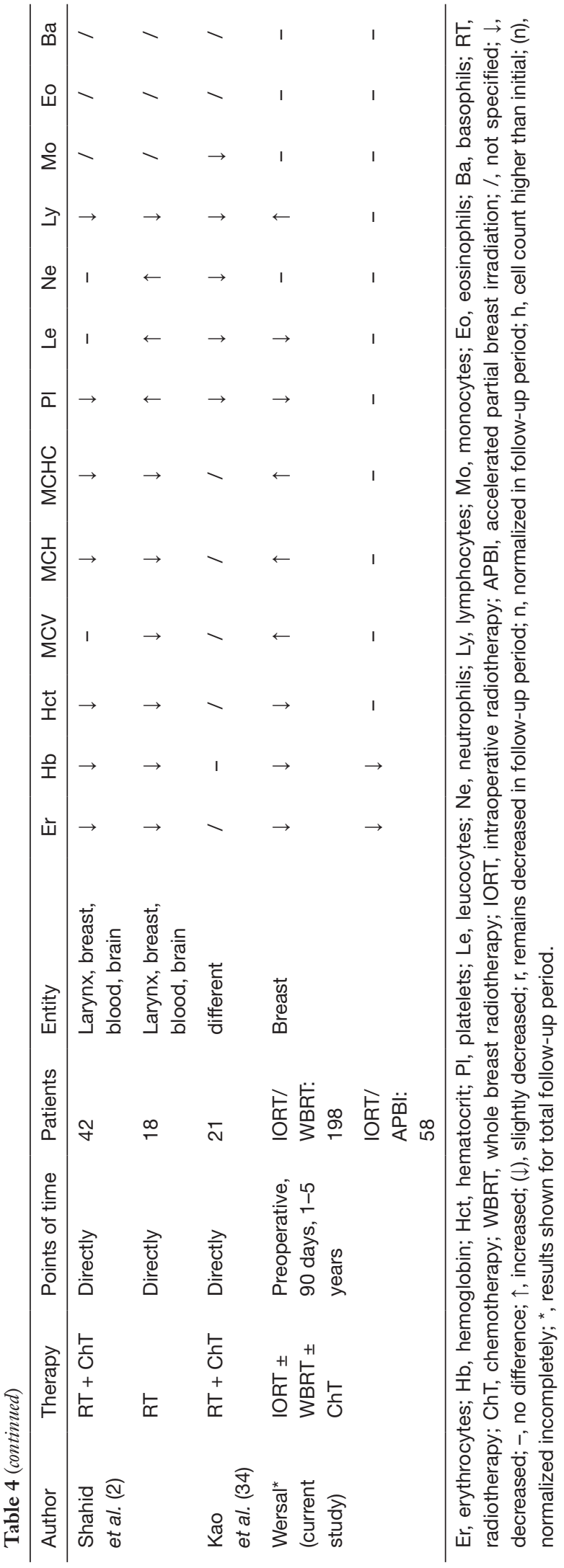

\section{Platelets}

Radiotherapy of breast cancer and other tumors can also have an effect on the number of circulating platelets. In contrast to the results of Shahid et al. showing slightly increased platelet counts, most studies found decreased platelet counts after radiotherapy $(2,29-31,34)$. In the analysis of Plowman et al., platelet counts recovered after 2 months at least partly, whereas Geinitz et al. could show decreased platelet counts even 2 months after radiotherapy of breast cancer $(24,30)$. The results of the current analysis showed significant decreases of platelet counts in almost every postoperative period in the IORT/WBRT-group as well. In contrast, no such significant decrease could be seen using IORT as APBI.

The most common causes of thrombocytopenia in tumor patients are chemotherapy and radiotherapy (40). Consequences of thrombocytopenia, other than hemorrhage, are the delay and reduction of chemo- or radiotherapy to avoid a further decrease in platelet counts (41). Ling et al. could show that an increase of platelets after the resection of esophagus carcinoma is associated with improved survival (42). In contrast, thrombocytosis in other malignant diseases correlated with poorer prognosis for recurrence-free and overall survival (OS) in several studies $(5,43)$. Many malignant diseases may cause paraneoplastic thrombocytosis. Cancer cells can activate platelets in different ways, which can be seen by increased plasma levels of markers of platelet activation in vivo. As activated platelets can stimulate tumor progression especially in terms of metastatic spread, a vicious circle can occur (44). On the other hand, thrombopenia or reduced platelet counts can counteract metastatic spread $(45,46)$.

Generally, platelets seem to have a negative effect on tumor diseases, so reduced platelet counts could be advantageous. However, it is not yet known, which effects a radiation-induced decrease of platelets has on carcinomas and if there is a difference between intraoperative and external beam radiotherapy. This should be content of further investigations.

\section{White blood cells}

Changes in leucocyte counts after radiotherapy of different tumor entities were investigated in several studies. While Shahid et al. showed a slight increase of leucocyte counts, in most other studies decreased leucocyte counts were found $(2,21,28,29,31,33,34)$. In the current analysis for the 
total group, the IORT/WBRT-group showed a significant decrease of leucocyte counts during the first year after BCS/ IORT as well. In contrast, no significant change could be seen in the IORT/APBI-group. In the analysis of patients without chemotherapy however, no significant changes could be found in the IORT/WBRT-group and a significant increase of leucocytes was shown in the first 90 days after BCS/IORT. Plowman et al. described the recovery of leucocyte counts two months after radiotherapy (24). In other studies, leucocyte counts were still decreased up to 5 years after radiotherapy $(25,26,30,32)$. Additionally, the degree of decrease was shown to be dependent on the delivered dose as well as simultaneous chemotherapy $(2,29)$.

Leucocytes are an important component of the innate and adaptive immune system of the human body. The decrease of leucocyte counts can impair the immune system and increase the risk for infections (47). Several of the above-mentioned studies could not find clinical relevance of leucopenia after radiotherapy $(29,31)$. Mild leucopenia after chemotherapy could even be associated with better survival, whereas severe leucopenia after chemotherapy correlated with poorer prognosis $(48,49)$. The degree of impairment of the immune system due to radio- or chemotherapy therefore seems to be dependent also on other factors than mere leucocyte counts. Hence, a closer look on leucocyte subpopulations and their interaction with tumors is necessary.

Neutrophils and lymphocytes form the largest part of leucocytes. Both of them show pro-tumor as well as anti-tumor functions (50). Irradiation seems to have the strongest effect on lymphocytes, as they responded most sensitive to it in several studies $(2,28,31,47)$. In the current analysis, there also was a significant change in lymphocyte counts in the IORT/WBRT-group over the total follow-up period, which could not be seen in the IORT/APBI-group. In the analysis of normal limits, a decrease of lymphocyte counts could be seen shortly after BCS/IORT, which recovered at the end of the follow-up period. Decreased lymphocyte counts correlated often with poorer prognosis $(27,51)$. Additional to quantitative changes, the functions of lymphocytes can be influenced as well. The regular reaction of lymphocytes to specific antigens can give information on the immune status and can be suppressed by carcinomas $(52,53)$. Fractionated radiotherapy can have similar effects on lymphocyte functions and it can therefore weaken the patient's immune system even more $(22,23)$. Lower radiation exposure due to IORT could be advantageous, by sparing the immune system.
There are various explanatory approaches, why radiotherapy can have effects on peripheral blood cells.

Bone marrow, harboring hematopoietic stem cells and main site for production of blood cells, is vulnerable to radiotherapy, as its tolerance dose is lower than that of other organs (20). Radiotherapy of breast cancer may lead to hypoplasia and aplasia of bone marrow within the sternum, that can still be seen after more than 10 years $(54,55)$. Irradiation of bone marrow with IORT is lower or marginal compared to standard EBRT due to rapid attenuation of dose in the surrounding tissue. On the other hand, the percentage of irradiated bone marrow and lymphatic tissue during radiotherapy of breast cancer is not really large enough to cause such long lasting changes $(29,30)$. In addition to that, studies showed, that blood counts recovered while the bone marrow was still hypoplastic and that there is no correlation between the regeneration of bone marrow and blood counts $(56,57)$.

The direct toxic effect of radiation or the effect of released toxic substances on circulating blood cells while irradiation of the breast as shown by Geinitz et al. might also have an impact on blood counts (30). Especially damage of DNA seems to play a major role in this (58). This might be more relevant when IORT is given in addition to WBRT in comparison to IORT as APBI as both irradiation time and volume is much higher when IORT is given as a boost.

Irradiation can lead to apoptosis of natural killer cells as well as T- and B-lymphocytes, especially when given in several fractions (59). Belletti et al. showed positive changes in cytokine expression and the whole micromilieu after IORT within the wound fluid (13). Fabris et al. also showed that proliferation of breast cancer cells is reduced by changes in expression of miR 223 after IORT by targeting the EGF pathway (14). And this was not only a local but systemic effect of IORT in mice and patients. Veldwijk et al. also showed a dose-dependent cohort effect after large single doses supporting the hypothesis that radiotherapy might cause non-targeted effects, especially after IORT (large single dose) (60). All these effects were described after IORT as APBI. One may speculate if these effects might disappear when fractionated EBRT of the whole breast is added. Especially the analysis of the patients without chemotherapy imply this hypothesis, as there was a significant increase in the IORT/APBI-group within day 1-90 (showing a stimulation of the immune system), while in the same period leucocytes were unaltered in the IORT/ WBRT-group. The interval between IORT and EBRT was $<90$ days in $123(62 \%)$ patients. So most patients in 
the IORT/WBRT-group have had started EBRT in this period of decrease of the leucocytes again supporting this hypothesis.

Altogether, low energy X-ray IORT as APBI seems to have less negative effects on blood cells, especially on white blood cell count, than IORT with additional WBRT in our analysis. This might be a possible explanation of positive systemic effects after IORT or APBI in general with a possible stimulation of the immune system and therefore maybe long-lasting effects on the outcome, especially survival, as shown in different randomized trials (Table 5) with different techniques for APBI. In the TARGIT A study even a significantly lower non-breast-cancer mortality for IORT compared to WBRT could be found (63). Vaidya et al. performed a meta-analysis concerning the outcome of APBI with different techniques with more than 5,000 patients (67).

The current analysis of PLR, NLR and dNLR supports a positive effect of IORT on outcome: At the end of the follow-up period more patients were below normal ranges than before surgery for all three ratios, which is related to better outcome (Figure 2). In several studies concerning different tumor entities, the pre-therapeutic ratios were independent prognostic factors for recurrence and survival $(10,11,17)$. Furthermore, newer studies could show post-therapeutic ratios to be prognostically relevant as well (68-70). Iwase et al. could also observe, that NLR is higher at the time of recurrence and that high NLR-values at the time of recurrence are associated with poorer prognosis. In addition, an increase between initial NLR and NLR at the time of recurrence indicates poorer prognosis (71). Similar associations could be seen for different tumor therapies. An increase of NLR or PLR during or after therapy was associated with poorer total and disease-free survival (DFS) in several studies $(70,72,73)$. Simultaneously, patients had a better prognosis if NLR decreased after chemotherapy or targeted therapy $(69,73)$. Therefore, also dynamic changes of PLR and NLR seem to be prognostically relevant.

Table 5 Overview of long-term outcomes after APBI with different techniques

\begin{tabular}{|c|c|c|c|c|c|c|}
\hline Author, year & Design & $\begin{array}{l}\text { Patient } \\
\text { number }\end{array}$ & $\begin{array}{l}\text { Median follow- } \\
\text { up (min, max) }\end{array}$ & Local recurrence & Survival & Other results \\
\hline \multirow[t]{10}{*}{$\begin{array}{l}\text { Veronesi et al., } \\
2013(61)\end{array}$} & Single-center & ITT: 1,305 & $\begin{array}{l}\text { All patients: } 5.8 \\
(4.1-7.7) \text { years }\end{array}$ & IBR (5 years) & OS (5 years) & $\begin{array}{l}\text { No significant } \\
\text { difference }\end{array}$ \\
\hline & Randomized & PPA: 1,186 & $\begin{array}{l}\text { WBI: } 5.9 \\
(4.2-7.8) \text { years }\end{array}$ & $\begin{array}{l}\text { PBI: 4.4\% (95\% } \\
\text { Cl, 2.7-6.1) }\end{array}$ & $\begin{array}{l}\text { PBI: } 96.8 \%(95 \% \\
\mathrm{Cl}, 95.3-98.3)\end{array}$ & $\begin{array}{l}\text { Contralateral BC } \\
(P=0.34)\end{array}$ \\
\hline & Prospective & & $\begin{array}{l}\text { PBI: } 5.5 \\
(4.0-7.4) \text { years }\end{array}$ & $\begin{array}{l}\text { WBI: } 0.4 \%(95 \% \\
\text { Cl, 0.0-1.0) }\end{array}$ & $\begin{array}{l}\text { WBI: } 96.9 \%(95 \% \\
\text { CI, 95.5-98.3) }\end{array}$ & $\begin{array}{l}\text { Distant metastasis } \\
(\mathrm{P}=0.94)\end{array}$ \\
\hline & $\begin{array}{l}\text { Parallel } \\
\text { assignment }\end{array}$ & & & $P=0.0001$ & $P=0.59$ & $\begin{array}{l}\text { Primary cancer other } \\
\text { sites }(P=0.88)\end{array}$ \\
\hline & Open label & & & TBR (5 years) & & $\begin{array}{l}\text { Significant different } \\
\text { side effects }\end{array}$ \\
\hline & & & & $\begin{array}{l}\text { PBI: } 2.5 \%(95 \% \\
\mathrm{Cl}, 1.2-3.8)\end{array}$ & & $\begin{array}{l}\text { Skin: in favor of } \mathrm{PBI} \\
(\mathrm{P}=0.0002)\end{array}$ \\
\hline & & & & $\begin{array}{l}\text { Regional recurrence } \\
\text { (5 years) }\end{array}$ & & $\begin{array}{l}\text { PPA: similar findings } \\
\text { for all results }\end{array}$ \\
\hline & & & & $\begin{array}{l}\text { PBI: } 1.0 \%(95 \% \\
\mathrm{Cl}, 0.2-1.9)\end{array}$ & & \\
\hline & & & & $\begin{array}{l}\text { WBI: } 0.3 \%(95 \% \\
\mathrm{Cl}, 0.0-0.8)\end{array}$ & & \\
\hline & & & & $P=0.03$ & & \\
\hline
\end{tabular}

Table 5 (continued) 
Translational Cancer Research, Vol 8, No 5 September 2019

Table 5 (continued)

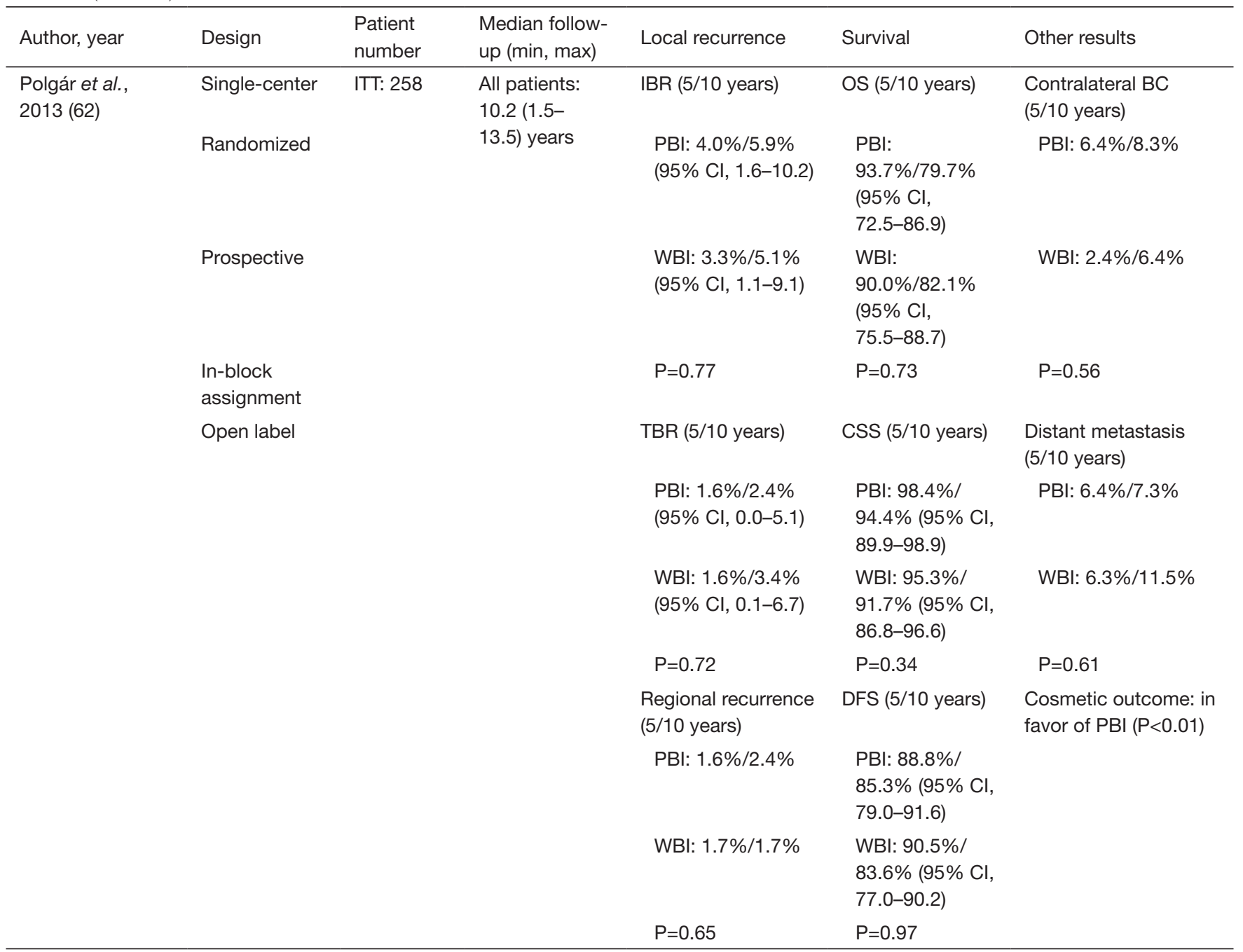

Table 5 (continued) 
Table 5 (continued)

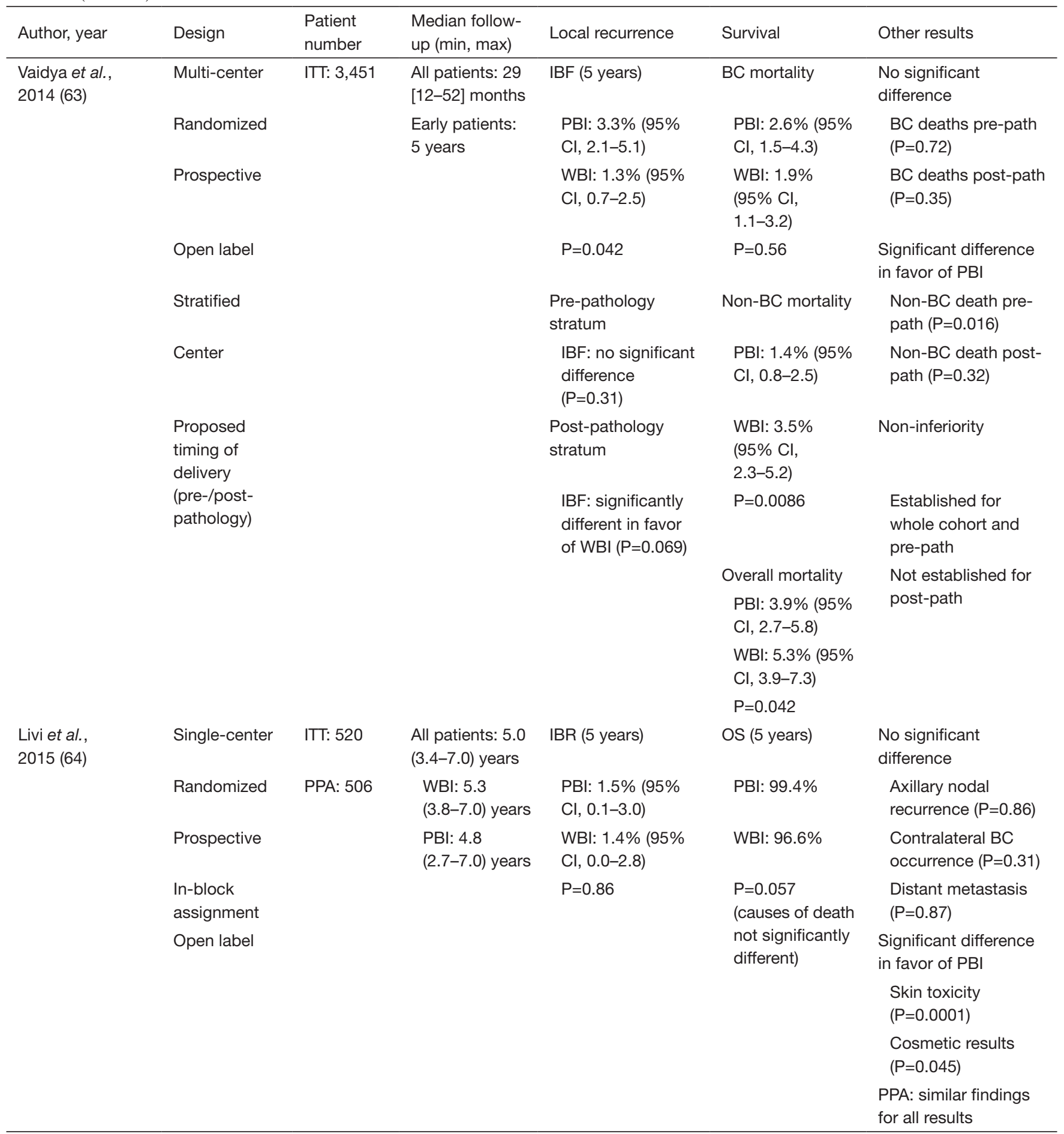

Table 5 (continued) 
Table 5 (continued)

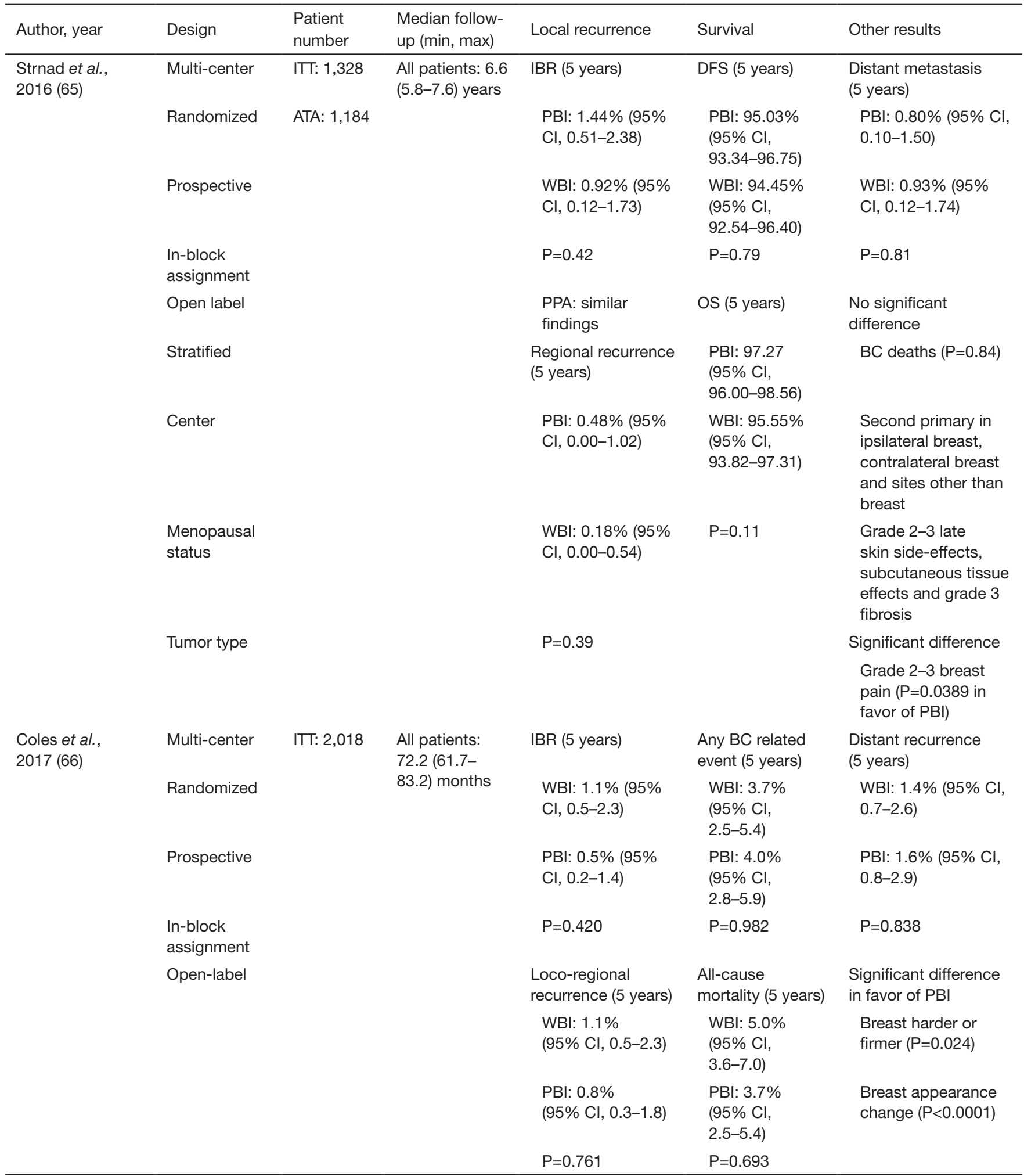

APBI, accelerated partial breast irradiation; ITT, intention-to-treat; PPA, per-protocol analysis; CI, confidence interval; ATA, as-treated analysis; WBI, whole breast irradiation; PBI, partial breast irradiation; BC, breast cancer; OS, overall survival; CSS, cancer-specific survival; DFS, disease-free survival; IBR, ipsilateral breast recurrence; TBR, tumor bed recurrence; IBF, in-breast failure. 


\section{Limitations}

Sample size, especially in the IORT/APBI-group, and decreasing number of available blood counts over time are a limiting factor of this analysis. Moreover, blood parameters are influenced by a wide range of diseases and the special role of IORT or irradiation in general is not clear. Due to the retrospective character of the current analysis, there is a high probability, that patients with available blood counts had other diseases or on the other hand presented cumulatively with an inconspicuous follow-up.

\section{Conclusions}

In the IORT/WBRT-group significant changes of blood counts were more frequent than in the IORT/APBI-group regardless of applied chemotherapy. IORT/APBI seems to have a smaller effect on blood counts compared to IORT/ WBRT. Furthermore, PLR-, NLR- and dNLR-values improved over time, suggesting a positive effect of IORT in general regarding outcome parameters.

\section{Acknowledgments}

The authors thank all patients who participated in this analysis and Anette Kipke and team for taking care of data and patient management.

Funding: This work was supported by the Ministry of Science and Art, Baden-Württemberg, Germany for a research grant to create evidence for IORT in breast cancer. We acknowledge financial support by Deutsche Forschungsgemeinschaft within the funding programme Open Access Publishing, by the Baden- Württemberg Ministry of Science, Research and the Arts and by Ruprecht-Karls-Universität Heidelberg.

\section{Footnote}

Conflict of Interests: Dr. Wersal has nothing to disclose. Mrs. Keller has nothing to disclose. Prof. Weiss has nothing to disclose. Dr. Giordano reports grants and personal fees from null, grants and personal fees from null, personal fees from null, personal fees from null, personal fees from null, personal fees from null, during the conduct of the study; other from Implacit $\mathrm{GmbH}$, non-financial support from Oncare GmbH, grants and personal fees from NOXXON Pharma AG, grants and personal fees from CARL ZEISS MEDITEC AG, personal fees from Bristol-Myers
Squibb, personal fees from Roche Pharma AG, personal fees from MSD Sharp and Dohme GmbH, personal fees from AstraZeneca $\mathrm{GmbH}$, outside the submitted work; in addition, Dr. Giordano has a patent (US 62/435405) pending. Dr. Abo-Madyan reports honoraria from CarlZeiss Meditec, outside the submitted work, honoraria from Merck-Serono, outside the submitted work, personal fees from Elekta. Dr. Ehmann reports other from Carl Zeiss Meditec AG, outside the submitted work. Dr. Tuschy has nothing to disclose. Dr. Sütterlin reports personal fees and other from Carl Zeiss Meditec AG, outside the submitted work. Dr. Wenz reports personal fees from Celgene GmbH, personal fees from Roche Pharma AG, personal fees from Eli Lilly and Company, personal fees from Ipsen Pharma $\mathrm{GmbH}$, grants and other from Carl Zeiss Meditec AG, grants and other from Elekta $\mathrm{AB}$, outside the submitted work; in addition, Dr. Wenz has a patent Carl Zeiss Meditec AG licensed. Dr. Sperk reports grants from Ministry for Science and Arts, during the conduct of the study; personal fees and other from Zeiss Meditec AG, outside the submitted work.

Ethical Statement: The authors are accountable for all aspects of the work in ensuring that questions related to the accuracy or integrity of any part of the work are appropriately investigated and resolved. This study was conducted in accordance with the Declaration of Helsinki (as revised in 2013). All patients approved the informed consent and the current analysis was also approved by the institutional review board (application number: 2016-866R-MA).

Open Access Statement: This is an Open Access article distributed in accordance with the Creative Commons Attribution-NonCommercial-NoDerivs 4.0 International License (CC BY-NC-ND 4.0), which permits the noncommercial replication and distribution of the article with the strict proviso that no changes or edits are made and the original work is properly cited (including links to both the formal publication through the relevant DOI and the license). See: https://creativecommons.org/licenses/by-nc-nd/4.0/.

\section{References}

1. Ferlay J, Soerjomataram I, Dikshit R, et al. Cancer incidence and mortality worldwide: sources, methods and major patterns in GLOBOCAN 2012. Int J Cancer 2015;136:E359-86.

2. Shahid S. Review of hematological indices of cancer 
patients receiving combined chemotherapy \& radiotherapy or receiving radiotherapy alone. Crit Rev Oncol Hematol 2016;105:145-55.

3. Coussens LM, Werb Z. Inflammation and cancer. Nature 2002;420:860-7.

4. Gao J, Hu JY, Xia YF, et al. Continuous fall in hemoglobin level is a poor prognostic factor in patients with nasopharyngeal carcinoma treated with radiotherapy. Chin J Cancer 2010;29:561-6.

5. He Y, Xia T, Bian H, et al. Pretreatment thrombocytosis predicts survival in colorectal cancer. Clin Res Hepatol Gastroenterol 2016;40:e59-60.

6. Schernberg A, Escande A, Rivin Del Campo E, et al. Leukocytosis and neutrophilia predicts outcome in anal cancer. Radiother Oncol 2017;122:137-45.

7. Iseki Y, Shibutani M, Maeda K, et al. The impact of the preoperative peripheral lymphocyte count and lymphocyte percentage in patients with colorectal cancer. Surg Today 2017;47:743-54.

8. Absenger G, Szkandera J, Pichler M, et al. A derived neutrophil to lymphocyte ratio predicts clinical outcome in stage II and III colon cancer patients. Br J Cancer 2013;109:395-400.

9. Krenn-Pilko S, Langsenlehner U, Thurner EM, et al. The elevated preoperative platelet-to-lymphocyte ratio predicts poor prognosis in breast cancer patients. Br J Cancer 2014;110:2524-30.

10. Templeton AJ, Ace O, McNamara MG, et al. Prognostic role of platelet to lymphocyte ratio in solid tumors: a systematic review and meta-analysis. Cancer Epidemiol Biomarkers Prev 2014;23:1204-12.

11. Proctor MJ, McMillan DC, Morrison DS, et al. A derived neutrophil to lymphocyte ratio predicts survival in patients with cancer. Br J Cancer 2012;107:695-9.

12. Leitlinienprogramm Onkologie. Interdisziplinäre S3leitlinie für die diagnostik, therapie und nachsorge des mammakarzinoms leitlinie (langversion). Langversion 3.0, Aktualisierung 2012 ed. Germering: Zuckschwerdt, 2012:382.

13. Belletti B, Vaidya JS, D'Andrea S, et al. Targeted intraoperative radiotherapy impairs the stimulation of breast cancer cell proliferation and invasion caused by surgical wounding. Clin Cancer Res 2008;14:1325-32.

14. Fabris L, Berton S, Citron F, et al. Radiotherapy-induced miR-223 prevents relapse of breast cancer by targeting the EGF pathway. Oncogene 2016;35:4914-26.

15. Wenz F, Blank E, Welzel G, et al. Intraoperative radiotherapy during breast-conserving surgery using a miniature $\mathrm{x}$-ray generator (Intrabeam $\left.{ }^{\circledR}\right)$ : theoretical and experimental background and clinical experience. Womens Health (Lond) 2012;8:39-47.

16. Azab B, Shah N, Radbel J, et al. Pretreatment neutrophil/ lymphocyte ratio is superior to platelet/lymphocyte ratio as a predictor of long-term mortality in breast cancer patients. Med Oncol 2013;30:432.

17. Dirican A, Kucukzeybek BB, Alacacioglu A, et al. Do the derived neutrophil to lymphocyte ratio and the neutrophil to lymphocyte ratio predict prognosis in breast cancer? Int J Clin Oncol 2015;20:70-81.

18. Koh CH, Bhoo-Pathy N, Ng KL, et al. Utility of pretreatment neutrophil-lymphocyte ratio and plateletlymphocyte ratio as prognostic factors in breast cancer. $\mathrm{Br}$ J Cancer 2015;113:150-8.

19. Templeton AJ, McNamara MG, Seruga B, et al. Prognostic role of neutrophil-to-lymphocyte ratio in solid tumors: a systematic review and meta-analysis. J Natl Cancer Inst 2014;106:dju124.

20. Wannenmacher M, Wenz F, Debus J. Strahlentherapie. 2. Auflage ed. Berlin: Springer, 2013:287-352.

21. Lundell G. Effects of radiation therapy on blood-borne leucocytes in patients with mammary carcinoma. Acta Radiol Ther Phys Biol 1974;13:307-12.

22. Blomgren H, Berg R, Wasserman J, et al. Effect of radiotherapy on blood lymphocyte population in mammary carcinoma. Int J Radiat Oncol Biol Phys 1976;1:177-88.

23. Baral E, Blomgren H, Petrini B, et al. Blood lymphocytes in breast cancer patients following radiotherapy and surgery. Int J Radiat Oncol Biol Phys 1977;2:289-95.

24. Plowman PN. The effects of conventionally fractionated, extended portal radiotherapy on the human peripheral blood count. Int J Radiat Oncol Biol Phys 1983;9:829-39.

25. Toivanen A, Granberg I, Nordman E. Lymphocyte subpopulations in patients with breast cancer after postoperative radiotherapy. Cancer 1984;54:2919-23.

26. Shukla HS, Hughes LE, Whitehead RH, et al. Long-term follow-up of general immune competence in breast cancer. II. Sequential pre- and post-treatment levels: a 10 year study. Cancer Immunol Immunother 1986;21:6-11.

27. Hu DE, Ling XS, Hu J, et al. The effects of radiotherapy on the immune system of patients with nasopharyngeal carcinoma. Br J Radiol 1988;61:305-8.

28. Kuhnt T, Richter C, Enke H, et al. Acute radiation reaction and local control in breast cancer patients treated with postmastectomy radiotherapy. Strahlenther Onkol 1998;174:257-61.

29. Kleinberg L, Grossman SA, Piantadosi S, et al. The 
effects of sequential versus concurrent chemotherapy and radiotherapy on survival and toxicity in patients with newly diagnosed high-grade astrocytoma. Int J Radiat Oncol Biol Phys 1999;44:535-43.

30. Geinitz H, Zimmermann FB, Stoll P, et al. Fatigue, serum cytokine levels, and blood cell counts during radiotherapy of patients with breast cancer. Int J Radiat Oncol Biol Phys 2001;51:691-8.

31. Zachariah B, Jacob SS, Gwede C, et al. Effect of fractionated regional external beam radiotherapy on peripheral blood cell count. Int J Radiat Oncol Biol Phys 2001;50:465-72.

32. Standish LJ, Torkelson C, Hamill FA, et al. Immune defects in breast cancer patients after radiotherapy. J Soc Integr Oncol 2008;6:110-21.

33. Mellios T, Ko HL, Beuth J. Impact of adjuvant chemoand radiotherapy on the cellular immune system of breast cancer patients. In Vivo 2010;24:227-30.

34. Kao J, Timmins J, Ozao-Choy J, et al. Effects of combined sunitinib and extracranial stereotactic radiotherapy on bone marrow hematopoiesis. Oncol Lett 2016;12:2139-44.

35. Vaupel P, Thews O, Hoeckel M. Treatment resistance of solid tumors: role of hypoxia and anemia. Med Oncol 2001;18:243-59.

36. Semenza GL. Regulation of mammalian O2 homeostasis by hypoxia-inducible factor 1 . Annu Rev Cell Dev Biol 1999; 15:551-78.

37. Aapro M, Leonard RC, Barnadas A, et al. Effect of onceweekly epoetin beta on survival in patients with metastatic breast cancer receiving anthracycline- and/or taxane-based chemotherapy: results of the Breast Cancer-Anemia and the Value of Erythropoietin (BRAVE) study. J Clin Oncol 2008;26:592-8.

38. Gibson AD, Crawford J, Jain VK. Impact of correction of anemia on clinical outcome in patients with cancer: recent data from head and neck and breast cancer trials. Support Cancer Ther 2004;1:145-9.

39. Zhang Y, Chen Y, Chen D, et al. Impact of preoperative anemia on relapse and survival in breast cancer patients. BMC Cancer 2014;14:844.

40. Kuter DJ. Managing thrombocytopenia associated with cancer chemotherapy. Oncology (Williston Park) 2015;29:282-94.

41. Liebman HA. Thrombocytopenia in cancer patients. Thromb Res 2014;133 Suppl 2:S63-9.

42. Ling FC, Vallbohmer D, Hoelscher AH, et al. Increased platelet counts after transthoracic en bloc resection for esophageal cancer is associated with significantly improved survival. World J Surg 2010;34:2628-34.

43. Brown KM, Domin C, Aranha GV, et al. Increased preoperative platelet count is associated with decreased survival after resection for adenocarcinoma of the pancreas. Am J Surg 2005;189:278-82.

44. Li N. Platelets in cancer metastasis: To help the "villain" to do evil. Int J Cancer 2016;138:2078-87.

45. Gasic GJ, Gasic TB, Stewart CC. Antimetastatic effects associated with platelet reduction. Proc Natl Acad Sci U S A 1968;61:46-52.

46. Nieswandt B, Hafner M, Echtenacher B, et al. Lysis of tumor cells by natural killer cells in mice is impeded by platelets. Cancer Res 1999;59:1295-300.

47. Advisory Group on Ionising Radiation, Subgroup on High Dose Radiation and Tissue Effects. High dose radiation effects and tissue injury: report of the independent advisory group on ionising radiation. London: Health Protection Agency, 2009:94.

48. Bogani G, Sabatucci I, Maltese G, et al. Chemotherapyrelated leukopenia as a biomarker predicting survival outcomes in locally advanced cervical cancer. Eur J Obstet Gynecol Reprod Biol 2017;208:41-5.

49. Liu W, Zhang CC, Li K. Prognostic value of chemotherapy-induced leukopenia in small-cell lung cancer. Cancer Biol Med 2013;10:92-8.

50. Grivennikov SI, Greten FR, Karin M. Immunity, inflammation, and cancer. Cell 2010;140:883-99.

51. Riesco A. Five-year cancer cure: relation to total amount of peripheral lymphocytes and neutrophils. Cancer 1970;25:135-40.

52. Steward AM. Tuberculin reaction in cancer patients, "Mantoux release," and lymphosuppressive-stimulatory factors. J Natl Cancer Inst 1973;50:625-32.

53. Whittaker MG, Clark CG. Depressed lymphocyte function in carcinoma of the breast. Br J Surg 1971;58:717-20.

54. Sykes MP, Chu F, Gee TS, et al. Follow-up on the longterm effects of therapeutic irradiation on bone marrow. Radiology 1974;113:179-80.

55. Sykes MP, Savel H, Chu FC, et al. Long-Term Effects of Therapeutic Irradiation Upon Bone Marrow. Cancer 1964;17:1144-8.

56. Sykes MP, Chu FC, Wilkerson WG. Local bone-marrow changes secondary to therapeutic irradiation. Radiology 1960;75:919-24.

57. Rubin P, Landman S, Mayer E, et al. Bone marrow regeneration and extension after extended field irradiation in Hodgkin's disease. Cancer 1973;32:699-711. 
58. Bakkenist CJ, Czambel RK, Clump DA, et al. Radiation therapy induces the DNA damage response in peripheral blood. Oncotarget 2013;4:1143-8.

59. Park B, Yee C, Lee KM. The effect of radiation on the immune response to cancers. Int J Mol Sci 2014;15:927-43.

60. Veldwijk MR, Zhang B, Wenz F, et al. The biological effect of large single doses: a possible role for non-targeted effects in cell inactivation. PLoS One 2014;9:e84991.

61. Veronesi U, Orecchia R, Maisonneuve P, et al. Intraoperative radiotherapy versus external radiotherapy for early breast cancer (ELIOT): a randomised controlled equivalence trial. Lancet Oncol 2013;14:1269-77.

62. Polgár C, Fodor J, Major T, et al. Breast-conserving therapy with partial or whole breast irradiation: ten-year results of the Budapest randomized trial. Radiother Oncol 2013;108:197-202.

63. Vaidya JS, Wenz F, Bulsara M, et al. Risk-adapted targeted intraoperative radiotherapy versus wholebreast radiotherapy for breast cancer: 5 -year results for local control and overall survival from the TARGIT-A randomised trial. Lancet 2014;383:603-13.

64. Livi L, Meattini I, Marrazzo L, et al. Accelerated partial breast irradiation using intensity-modulated radiotherapy versus whole breast irradiation: 5-year survival analysis of a phase 3 randomised controlled trial. Eur J Cancer 2015;51:451-63.

65. Strnad V, Ott OJ, Hildebrandt G, et al. 5-year results of accelerated partial breast irradiation using sole interstitial multicatheter brachytherapy versus whole-breast irradiation with boost after breast-conserving surgery for low-risk invasive and in-situ carcinoma of the female breast: a randomised, phase 3, non-inferiority trial. Lancet 2016;387:229-38.

Cite this article as: Wersal C, Keller A, Weiss C, Giordano FA, Abo-Madyan Y, Tuschy B, Sütterlin M, Wenz F, Sperk E. Long-term changes in blood counts after intraoperative radiotherapy for breast cancer-single center experience and review of the literature. Transl Cancer Res 2019;8(5):1882-1903. doi: $10.21037 /$ tcr.2019.09.05
66. Coles CE, Griffin CL, Kirby AM, et al. Partial-breast radiotherapy after breast conservation surgery for patients with early breast cancer (UK IMPORT LOW trial): 5-year results from a multicentre, randomised, controlled, phase 3, non-inferiority trial. Lancet 2017;390:1048-60.

67. Vaidya JS, Bulsara M, Wenz F, et al. Targeted radiotherapy for early breast cancer. Lancet 2018;391:26-7.

68. Sung S, Son SH, Park EY, et al. Prognosis of locally advanced rectal cancer can be predicted more accurately using pre- and post-chemoradiotherapy neutrophillymphocyte ratios in patients who received preoperative chemoradiotherapy. PLoS One 2017;12:e0173955.

69. Yoshida T, Kinoshita H, Yoshida K, et al. Perioperative change in neutrophil-lymphocyte ratio predicts the overall survival of patients with bladder cancer undergoing radical cystectomy. Jpn J Clin Oncol 2016;46:1162-7.

70. D'Emic N, Engelman A, Molitoris J, et al. Prognostic significance of neutrophil-lymphocyte ratio and plateletlymphocyte ratio in patients treated with selective internal radiation therapy. J Gastrointest Oncol 2016;7:269-77.

71. Iwase T, Sangai T, Sakakibara M, et al. An increased neutrophil-to-lymphocyte ratio predicts poorer survival following recurrence for patients with breast cancer. Mol Clin Oncol 2017;6:266-70.

72. Cho KM, Park H, Oh DY, et al. Neutrophil-tolymphocyte ratio, platelet-to-lymphocyte ratio, and their dynamic changes during chemotherapy is useful to predict a more accurate prognosis of advanced biliary tract cancer. Oncotarget 2017;8:2329-41.

73. Templeton AJ, Knox JJ, Lin X, et al. Change in neutrophilto-lymphocyte ratio in response to targeted therapy for metastatic renal cell carcinoma as a prognosticator and biomarker of efficacy. Eur Urol 2016;70:358-64. 